\title{
Detection of alien genetic introgressions in bread wheat using dot-blot genomic hybridisation
}

\author{
María -Dolores Rey • Pilar Prieto
}

Received: 4 October 2016 / Accepted: 1 February 2017 /Published online: 9 March 2017

(C) The Author(s) 2017. This article is published with open access at Springerlink.com

\begin{abstract}
Simple, reliable methods for the identification of alien genetic introgressions are required in plant breeding programmes. The use of genomic dot-blot hybridisation allows the detection of small Hordeum chilense genomic introgressions in the descendants of genetic crosses between wheat and $H$. chilense addition or substitution lines in wheat when molecular markers are difficult to use. Based on genomic in situ hybridisation, DNA samples from wheat lines carrying putatively $H$. chilense introgressions were immobilised on a membrane, blocked with wheat genomic DNA and hybridised with biotin-labelled $H$. chilense genomic DNA as a probe. This dot-blot screening reduced the number of plants necessary to be analysed by molecular markers or in situ hybridisation, saving time and money. The technique was sensitive enough to detect a minimum of $5 \mathrm{ng}$ of total genomic DNA immobilised on the membrane or about $1 / 420$ dilution of $H$. chilense genomic
\end{abstract}

Key message An efficient and user-friendly method has been optimised in the present work for the screening of small random genetic introgressions from alien species into the wheat background.

M.-D. Rey $\cdot$ P. Prieto $(\bowtie)$

Plant Breeding Department, Institute for Sustainable Agriculture, Agencia Estatal Consejo Superior de Investigaciones Científicas (CSIC), Alameda del Obispo s/n, 14080 Córdoba, Spain e-mail: pilar.prieto@ias.csic.es

Present Address:

M.-D. Rey

Crop Genetics Department, John Innes Centre, Norwich NR4

$7 \mathrm{UH}, \mathrm{UK}$
DNA in the wheat background. The robustness of the technique was verified by in situ hybridisation. In addition, the detection of other wheat relative species such as Hordeum vulgare, Secale cereale and Agropyron cristatum in the wheat background was also reported.

Keywords Dot-blot hybridisation - Genomic introgressions $\cdot H$. chilense $\cdot$ Bread wheat

\section{Introduction}

The introgression of genetic material from wild or distantly related species into wheat germplasm is a classical and effective approach for broadening the genetic basis of this crop. Hybridisation with bread wheat-related species makes it possible to transfer agronomically useful genes from those relative species into the wheat background. For example, wheat is affected by several fungal diseases; biototrophic fungi cause leaf and stripe rust diseases, as do powdery mildew or necrotrophic fungi such as Septoria tritici and Fusarium graminearum (Duveiller et al. 2007). Many relatives such as Hordeum species can be used as genetic tools to transfer resistance genes for these diseases into wheat. For example, there are genes conferring resistance to powdery mildew on Hordeum vulgare chromosome $1 \mathbf{H}^{\mathbf{v}}$ (Graner et al. 1991), genes conferring resistance to Puccinia graminis on $H$. vulgare chromosomes $5 \mathbf{H}^{\mathbf{v}}$ and $\mathbf{7} \mathbf{H}^{\mathbf{v}}$ (Kleinhofs et al. 1993; Borovkova et al. 1995), genes conferring resistance to Septoria tritice on $H$. chilense chromosome $4 \mathbf{H}^{\text {ch }}$ (Rubiales et al. 2000) 
and tolerance to greenbug (Schizaphis graminum Rond.) on chromosome $\mathbf{5} \mathbf{H}^{\text {ch }}$ from $H$. chilense (Castro et al. 2011). Hordeum chilense chromosome addition and substitution lines were developed in bread wheat and used for the transfer of wild barley genes into wheat (Miller et al. 1982). Similar cytogenetic stocks have been developed involving the cultivated barley H. vulgare (Islam et al. 1978, 1981; Szakács and Molnár-Láng 2006; Molnár-Láng et al. 2012) and rye (Secale cereale L.) chromosomes (Chapman and Riley 1955; Riley and Chapman 1958a; Miller 1984).

Breeders use genetic crosses to introduce into crops desirable genes from exotic germplasms, but sexual hybridisation between polyploid wheat and wild species generally produces an interspecific hybrid containing a haploid set of polyploid and wild relative chromosomes. In many such hybrids, there is only a low level of pairing and recombination between wheat and wild relative chromosomes. This failure of homoeologous (related) pairing during meiosis between wheat chromosomes and those from the related species is mainly due to the Ph1 locus (Okamoto 1957; Riley and Chapman 1958b; Sears and Okamoto 1958; Sears 1977). Since the characterisation of the $P h 1$ locus, its absence ( $p h 1 b$ mutant) has been used widely and successfully in wheat to induce homoeologous pairing and recombination (Sears 1977, 1981, 1982; Riley et al. 1968; Lukas zewki, 2000; Qi et al. 2008; Liu et al. 2011; Zhao et al. 2013). In the absence of the Phl locus, all chromosomes can remodel without requiring the presence of identical or near-identical chromosomes, and this increases the chance of pairing between related and wheat chromosomes (Prieto et al. 2004a; Lukaszewki 2000; Rey et al. 2015). In fact, the use of the phlb mutant allowed the linkage drag of the relative species in the wheat background to reduce and obtained recombinants between those relatives and bread wheat (Lukaszewki 2000; Rey et al. 2015). Thus, recombination can be possible between related chromosomes using the $p h 1 b$ mutant, although crossovers still occur randomly between homoeologues from both species. Other methods have been used in breeding to introgress desirable characters from related species into bread wheat. For example, ionising radiation has been applied to induce random chromosome breaks to transfer resistance genes from Aegilops umbellulata Zhuk., Agropyron intermedium, Agropyron elongatum or rye into wheat (Sears 1956; Friebe et al. 1993, 1995). Wheat-barley translocation lines have been also obtained by using gametocidal genes (Gc genes) of Aegilops cylindrical Host. (Endo et al. 1998) and derivatives of hybrids multiplied in vitro (Molnár-Láng et al. 2000). However, all these methods are random and the linkage drag is not reduced.

The screening and identification of alien genomic introgressions in the descendence of interspecific genetic crosses can be difficult, especially when chromosome pairing and recombination occur randomly and the alien genomic introgressions have been obtained arbitrarily in the background of a crop species. Particularly in wheat, this is also limited by the complexity of its genome and the high level of synteny among wheat and related species (Moore et al. 1995; Salse and Feuillet 2007). The use of molecular markers combined with in situ hybridisation is very useful for finding exogenous genetic introgressions (Schwarzacher et al. 1989; Calderón et al. 2012; Zhao et al. 2013), but the exogenous chromosome fragment needs to be previously identified and well characterised in order to choose specific molecular markers that will allow the alien sequence to be unequivocally distinguished from the equivalent chromosome region in wheat, which can sometimes be difficult. In addition, in situ hybridisation enables the determination of the exact chromosomal compositions in the descendence of genetic crosses between wheat and related species (Prieto et al. 2001). However, although in situ hybridisation is an enormously informative genetic approach, it requires high expertise and is time consuming, making the cytogenetic approach expensive when there is a need to analyse hundreds of plants resulting from genetic crosses. Thus, breeders must be provided with reliable and user-friendly methods of rapid assessment that can be routinely applied when large numbers of plants have to be screened.

Although dot-blotting is a simple method and expected to be suitable for analyses of large numbers of samples with low cost, it has not been adopted much in plant genome studies. Dot-blot hybridisation has been used since the 1980s as a routine assay to detect, for example, RNA sequences from small cultured cell samples (Cheley and Anderson 1984) or the presence of viruses in human tissues (Achim et al. 1994) and to measure the telomere DNA content (Kimura and Aviv 2011). This technique is extensively used in plants to detect viruses or pathogen infections (Owens and Diener 1981; Liu et al. 2007; Vassilakos et al. 2012; Azza and Eman 2016), evaluate intergeneric Saccharum $\times$ Erianthus hybrids (Besse et al. 1997) and for the identification of 
species in the tribe Brassiceae using repetitive DNA sequences (Tonosaki and Nishio 2010), among other numerous examples. In the present study, we have adapted and optimised the genomic dot-blot hybridisation technique to be used as a routine and low-cost tool to rapidly screen a large population of plants carrying small random chromosome introgressions from $H$. chilense in the wheat background in a breeding programme framework. In addition, the technique was also tested for other wheat relative species that are also used in wheat breeding programmes. The high accuracy and feasibility of the genomic dot-blot technique to analyse many individuals could facilitate the screening and selection of plants carrying alien genetic introgressions in a crop breeding programme.

\section{Materials and methods}

\section{Plant material}

The plant material used in this work included the wild barley $H$. chilense Roem. et Schult., wheat lines (T. aestivum cv. Chinese Spring) carrying either one or two full copies of a $H$. chilense chromosome (monosomic or disomic $H$. chilense addition lines; $2 n=6 x+$ $1=43$ and $2 n=6 x+2=44$, respectively), wheat lines having one or two copies of a telosomic $H$. chilense chromosome (monotelosomic and ditelosomic $H$. chilense addition lines; $2 n=6 x+1 t=42+1 t$ and $2 n=6 x+2 t=42+2 t$, respectively) and wheat lines carrying a copy of a distal introgression of chromosome $4 \mathbf{H}^{\mathbf{c h}}$ from $H$. chilense (approximately $1 / 10$ of the total chromosome length) which is about a 1/420 dilution of $H$. chilense DNA in the wheat background . In addition, $H$. vulgare, $S$. cereale and Agropyron cristatum species were also included in this work. All the lines were kindly supplied by Dr. Steve Reader (JIC, Norwich, UK) except the wheat line carrying the distal $H$. chilense introgression of chromosome $4 \mathbf{H}^{\text {ch }}$, which was developed in our lab (Rey et al. 2015).

Dot-blot genomic hybridisation

The total genomic DNA was extracted from frozen seedling leaves following the Murray and Thompson (1980) procedure and modified by Hernández et al. (2001). The quality and the concentration of the DNA were verified by electrophoresis in $1 \%$ agarose gel. Genomic DNA samples (200 ng) were blotted onto nylon membranes (Hybond $\mathrm{N}^{+}$, Amersham International, Buckinghamshire, UK) and were prehybridised for $30 \mathrm{~min}$ at $75{ }^{\circ} \mathrm{C}$ in $50 \%$ formamide, $2 \times$ saline-sodium citrate (SSC), $0.1 \%$ sodium dodecyl sulphate (SDS) and 2\% blocking reagent (Roche Diagnostics, Meylan, France) with gentle shaking. The hybridisation mixture, consisting of $50 \%$ formamide, $2 \times \mathrm{SSC}, 0.1 \% \mathrm{SDS}$ and $600 \mathrm{ng}$ of biotin-genomic DNA probe $(H$. chilense, $H$. vulgare, $S$. cereale or A. cristatum, depending on the experiment), was added to the prehybri disation buffer. The total genomic DNA used as a probe was labelled by nick translation with biotin11-dUTP (Boehringer Mannheim Biochemicals, Germany). The total wheat genomic DNA was also denatured at $99{ }^{\circ} \mathrm{C}$ for $1 \mathrm{~h}$ in a DNA thermal cycler (Veriti ${ }^{\mathrm{TM}}$ Thermal Cycler, Thermo Fisher Scientific, Somerset, New Jersey, USA) to allow fragmentation into pieces of 100-200 bp in size and employed as blocking DNA in the hybridisation mixture. H. chilense DNA probe and wheat blocking DNA were used in a 1:300 ratio in the hybridisation mixture. Hybridisation was conducted at $75{ }^{\circ} \mathrm{C}$ for 8 min followed by an overnight incubation at $37^{\circ} \mathrm{C}$. After hybridisation, the membrane was incubated in a Petri dish ( $9 \mathrm{~cm}$ diameter) with $100 \mathrm{mM}$ Tris- $\mathrm{HCl}(\mathrm{pH} 7.5)$ and $15 \mathrm{mM} \mathrm{NaCl}$ (buffer 1) for $1 \mathrm{~min}$, followed by incubation in a blocking buffer $(0.5 \%(w / v)$ blocking reagent from Roche Diagnostics Meylan, France) diluted in $100 \mathrm{mM}$ Tris-HCl (pH 7.5) and $15 \mathrm{mM} \mathrm{NaCl}$ (buffer 2) for $30 \mathrm{~min}$, shaking gently. The membrane was incubated with the antibiotin IgG Fab fragment conjugated with alkaline phosphatase (MACS, Bergisch Gladbach, Germany) diluted $1: 100$ in buffer 1 at $37^{\circ} \mathrm{C}$ for $30 \mathrm{~min}$, shaking gently. After the antibody incubation, the membrane was washed in buffer 1 for $15 \mathrm{~min}$ and then transferred to the detection buffer (buffer 3, $100 \mathrm{mM}$ Tris- $\mathrm{HCl}, \mathrm{pH}$ 9.5; $100 \mathrm{mM} \mathrm{NaCl}$; $50 \mathrm{mM} \mathrm{MgCl}$ ) for $2 \mathrm{~min}$. Finally, the hybridisation signals were developed by adding NBT (4-nitroblue tetrazolium chloride, $70 \%$ dimethylformamide; Sigma, St. Louis, MO, USA) and BCIP (5-bromo-4chloro-2-indolylphosphate, $50 \mathrm{mg} / \mathrm{ml}$ in $70 \%$ dimethylformamide; Sigma, St. Louis, MO, USA) for 3 min in buffer 3 in the dark until the colour was fully developed. The membrane was then washed in distilled water and air-dried. 
Genomic in situ hybridisation

Total $H$. chilense genomic DNA was also labelled by nick-translation with biotin-11-dUTP (Boehringer Mannheim Biochemicals, Germany) or digoxigenin-11-dUTP (Roche Applied Science, Indianapolis, IN, USA) and used as a probe. The in situ hybridisation protocol was performed according to Prieto et al. (2004b). The amount of either the biotin- or digoxigenin-labelled probes in the hybridisation mixture was $5 \mathrm{ng}$. Unlabelled wheat genomic DNA was used as blocking DNA at a ratio of 1:50 (probe/blocking DNA). Biotin-labelled $H$. chilense DNA and digoxigenin-labelled $H$. chi lense DNA were detected with a streptavidin-Cy3 conjugate (Sigma, St. Louis, MO, USA) and antidigoxigenin-FITC (Roche Diagnostics, Meylan, France), respectively. Chromosomes were counterstained with DAPI (4',6-diamidino-2-phenylindole) and mounted in Vectashield (Vector Laboratories, Burlingame, CA, USA). Hybridisation signals were visualised using a Nikon Eclipse 80i epifluo rescence microscope. Images were captured with a Nikon CCD camera using the Nikon 3.0 software (Nikon Instruments Europe BV, Amstelveen, The Netherlands) and processed with Photoshop 4.0 software (Adobe Systems Inc., San Jose, CA, USA).

\section{Results}

With the aim of establishing the minimum amount of genomic DNA detectable in a dot-blot hybridisation, different amounts ranging from $400 \mathrm{ng}$ down to $5 \mathrm{ng}$ of total genomic DNA from $H$. chilense were loaded on a membrane and were hybridised using biotin-labelled total $H$. chilense genomic DNA as a probe. The dot-blot assay showed positive signals for all dots except when $1 \mathrm{ng}$ of the total genomic DNA was loaded, revealing that the minimum amount of genomic DNA which is possible to detect using this technique was as little as 5 ng (Fig. 1).

To unequivocally detect $H$. chilense DNA in the background of the wheat genome and minimise wheat unspecific hybridisation signals due to common repetitive sequences between wheat and $H$. chilense, the total wheat genomic DNA was used as blocking DNA in the dot-blot experiments. Thus, it was necessary to establish the probe/blocking DNA ratio firstly to avoid false positives. A dot-blot experiment was carried out by loading two drops of $100 \mathrm{ng}$ of $\mathrm{H}$. chilense and wheat DNA, respectively, on three different membranes, which were simultaneously incubated with a different ratio of the $H$. chilense probe/blocking wheat genomic DNA in the hybridisation mixture $(1: 100,1: 200$ and 1:300). The drop of $H$. chilense genomic DNA was used as a positive control in each membrane. We found that

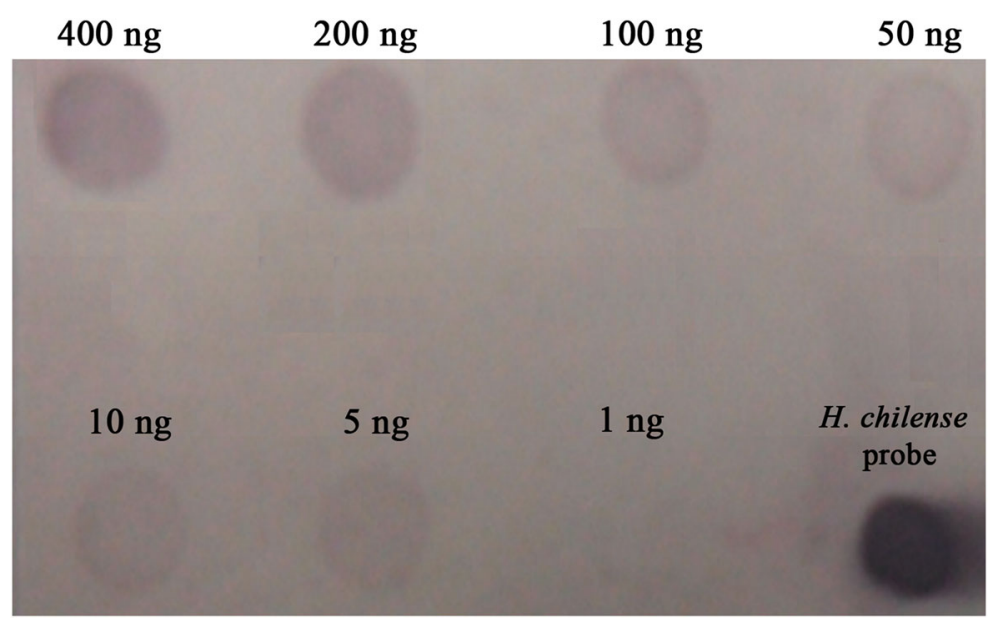

Fig. 1 Dot-blot hybridisation experiment carried out to establish the minimum amount of total Hordeum chilense genomic DNA that can be detected by this technique. Biotin-labelled H. chilense DNA was used as a probe. Several $H$. chilense amounts of DNA ranging from 400 to $1 \mathrm{ng}$ were loaded on the membrane. Positive signals were detected for all $H$. chilense amounts of DNA except when $1 \mathrm{ng}$ of DNA was loaded. The minimum amount of total $H$. chilense DNA detected was 5 ng. A drop of biotin-labelled $H$. chilense DNA was used as a positive control of the procedure 
only when the wheat blocking DNA was 300 times more abundant than the $H$. chilense probe in the hybridisation buffer did the dot containing the wheat genomic DNA remain negative (data not shown). This meant that the ratio between the probe and the blocking DNA should be 1:300 in order to avoid false positives, due to the presence of common $H$. chilense repetitive sequences in wheat, when screening $H$. chilense genetic introgressions in the wheat background.

Once we determined the minimum amount of total genomic DNA detectable by this method and the ratio of the probe and the blocking DNA to avoid false positives, we tried to determine the sensitivity of this technique when the $H$. chilense genomic DNA was diluted in the background of bread wheat genome. Thus, genomic DNA from different wheat lines carrying different $H$. chilense chromosome introgressions of different sizes (disomic and monosomic H. chilense addition lines in bread wheat, monotelosomic and ditelosomic $H$. chilense addition lines and the wheat line carrying one copy of a distal fragment $H$. chilense chromosome 4) were loaded on a membrane. In fact, these wheat lines were chosen as representatives of $H$. chilense introgression lines that can usually be obtained in a breeding programme when different genetic crosses between, for example, wheat and $H$. chilense addition lines in wheat have been carried out. Dot-blot hybridisation results showed that it was possible to detect all these $H$. chilense genomic introgressions in the background of hexaploid wheat (Fig. 2). Moreover, the size of the $H$. chilense did not seem to be a limiting factor in this experiment to identify wheat plants carrying $H$. chilense genomic introgressions that represents at least $1 / 10$ of a wheat chromosome, among 42 wheat chromosomes, which means approximately a 1/420 dilution of the $H$. chilense DNA in the wheat background (Fig. 2). The results obtained in the dot-blot analysis were confirmed by in situ hybridisation experiments developed in somatic cells in metaphase from the same wheat lines carrying one or two copies of an $H$. chilense chromosome, a monotelosomic or ditelosomic $H$. chilense chromosome or a distal small $H$. chilense chromosome segment in the wheat background (Fig. 3).

Once we demonstrated that the dot-blot analysis could be used to detect $H$. chilense chromosome introgressions in the wheat background, we developed the assay in the descendence of a genetic cross between the (4B) $4 \mathbf{H}^{\text {ch }}$ monosomic substitution line and the phlb wheat mutant line to detect those plants carrying an H. chilense chromosome introgression (Fig. 4). DNA from 15 different plants were loaded on the membrane and hybridised with the $H$. chilense DNA as probe. Nine

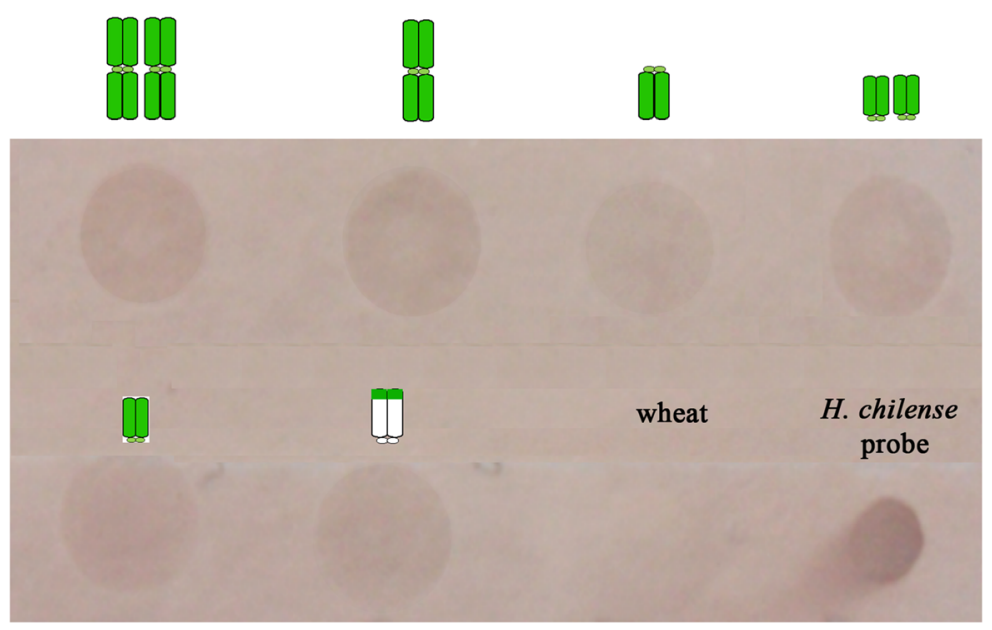

Fig. 2 Dot-blot hybridisation assay in Hordeum chilense addition lines in bread wheat using biotin-labelled $H$. chilense DNA as a probe. Chromosomes in green represent the number of copies of the $H$. chilense chromosomes in the wheat background for each substitution line. Two hundred nanograms of total genomic DNA were loaded per sample. From up left to down right: $4 \mathbf{H}^{\text {ch }}$ disomic addition line (two copies of $H$. chilense chromosomes); (4B) $4 \mathbf{H}^{\mathbf{c h}}$ monosomic substitution line (one copy of a $H$. chilense chromosome); $7 \mathbf{H}^{\text {ch }} \mathrm{L}$ monotelosomic addition line in wheat (one copy of one $H$. chilense chromosome arm); $6 \mathbf{H}^{\text {ch }} \mathrm{S}$ ditelosomic addition line in wheat (two copies of one $H$. chilense chromosome arm); $6 \mathbf{H}^{\mathbf{c h}} \mathrm{S}$ monotelosomic addition line in wheat (one copy of one $H$. chilense chromosome arm) and wheat line carrying a distal $4 \mathbf{H}^{\text {ch }} \mathrm{L}$ segment (one copy of the distal region of the H. chilense chromosome). Positive signals were revealed for all samples. Wheat DNA was used as a negative control. A drop of biotinlabelled $H$. chilense DNA was used as a positive control of the procedure 

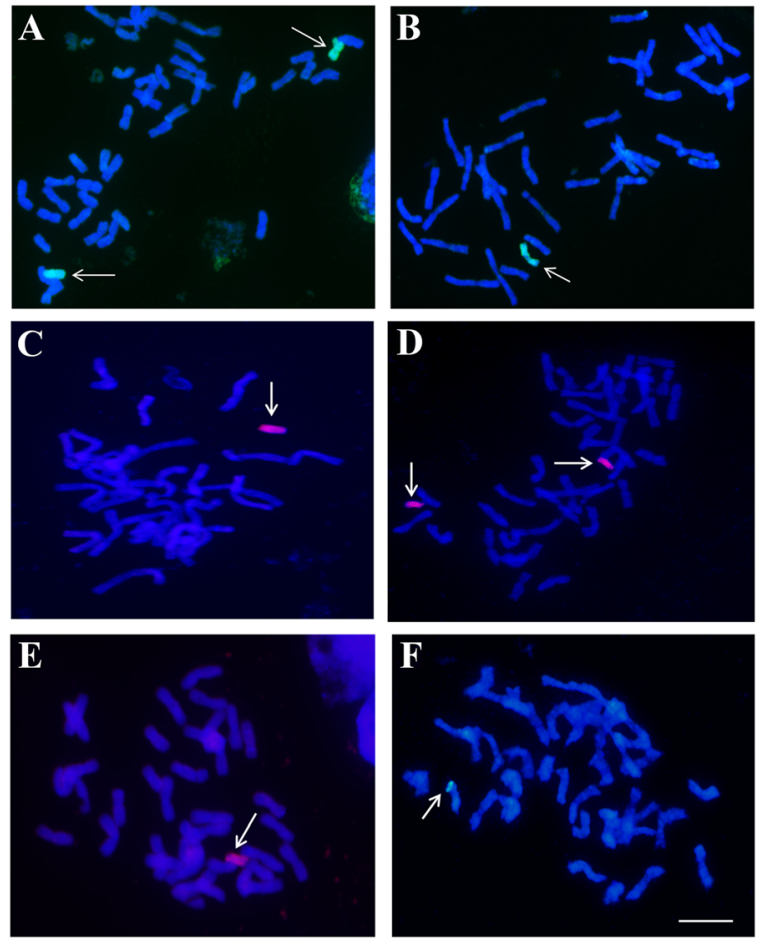

Fig. 3 Genomic in situ hybridisation in Hordeum chilense introgression lines in bread wheat using biotin and digoxigenin-labelled H. chilense genomic DNA as probes, detected with streptavidinCy3 conjugates (red) and antidigoxigenin-FITC (green), respectively. a Chromosome $4 \mathbf{H}^{\text {ch }}$ disomic addition line; b $(4 \mathbf{B}) 4 \mathbf{H}^{\text {ch }}$ monosomic substitution line; $\mathbf{c}$ monotelosomic line for chromosome $7 \mathbf{H}^{\text {ch }} \mathrm{L} ; \mathbf{d} 6 \mathbf{H}^{\text {ch }} \mathrm{S}$ ditelosomic line; e $6 \mathbf{H}^{\text {ch }} \mathrm{S}$ monotelosomic line; $\mathbf{f}$ wheat line carrying one copy of a distal $4 \mathbf{H}^{\mathbf{c h}} \mathrm{L}$ segment on 4D chromosome. Scale bar represents $10 \mu \mathrm{m}$ for all panels positive signals were obtained, suggesting that these plants could carry an $H$. chilense introgression in the wheat background. Genomic in situ hybridisation was performed on these 15 lines, and results did confirm the dot-blot analysis (data not shown). Positive results corresponded to wheat lines carrying $H$. chilense introgressions and negative results corresponded to wheat lines with no $H$. chilense introgressions. The method cannot inform whether it is as a full copy of one or two chromosomes or smaller genomic introgressions as the result of chromosome translocations or interspecific recombination between wheat and $H$. chilense chromosomes, but it can be used as a quick initial screening to target only those plants carrying putative $H$. chilense introgressions, which will be further analysed by in situ hybridisation, reducing the time and effort of a more detailed analysis, performed only on the desirable plants.

The reproducibility of the dot-blot hybridisation for the detection of $H$. chilense DNA in the background of the bread wheat was also tested. A dot-blot experiment was carried out by loading on the membrane total genomic DNA from three equivalent plants (biological replicates) of five wheat lines from the descendants of a genetic cross between the (4B) $4 \mathbf{H}^{\mathbf{c h}}$ monosomic substitution lines and the wheat $p h 1 b$ mutant. Two hundred nanogrammes of the total genomic DNA were loaded per sample. Positive signals were successfully detected in the three biological replicates carrying the same $H$. chilense chromosome introgression while negative
Fig. 4 Dot-blot hybridisation in the descendence of a genetic cross between the (4B) $4 \mathbf{H}^{\mathrm{ch}}$ monosomic substitution line and the wheat $p h 1 b$ mutant. Two hundred nanograms of total genomic DNA from 15 plants were loaded on the membrane. Positive signals corresponded to those plants carrying Hordeum chilense genetic introgressions in the wheat background. A drop of biotin-labelled $H$. chilense DNA and total wheat genomic DNA were used as positive and negative controls, respectively

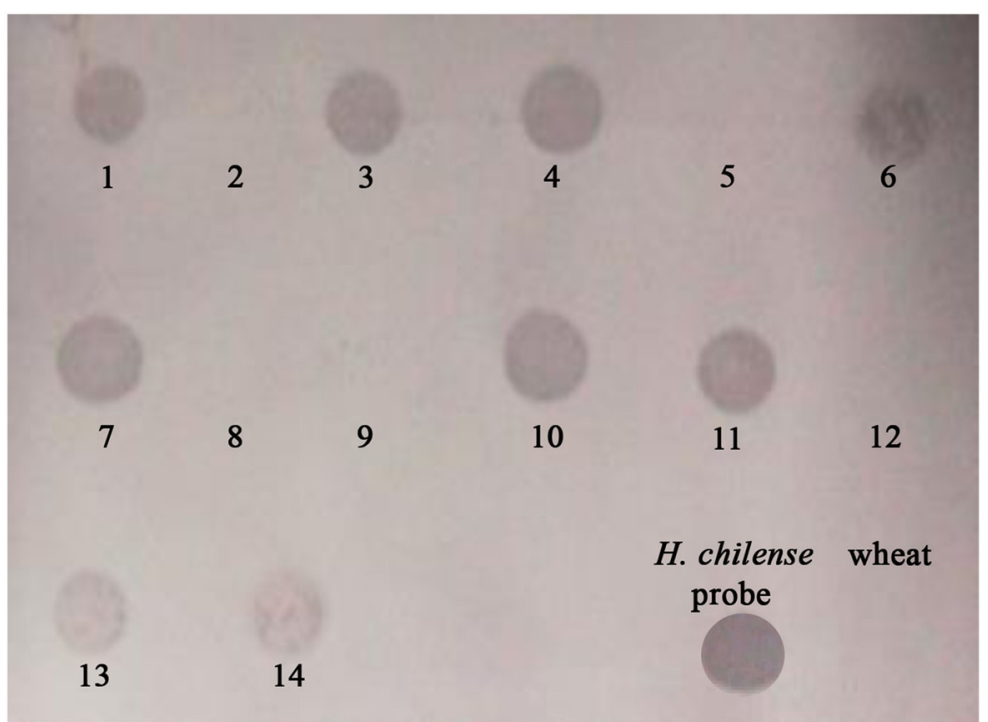


signals were consistent for the three replicates of each wheat line with no $H$. chilense genetic introgressions (Fig. 5). In addition, an equivalent experiment was repeated (technical replicate) and the observations were confirmed (data not shown). Thus, results indicated that the dot-blot hybridisation assay is a robust and reproducible method to detect $H$. chilense genomic introgressions in the wheat background easily.

Finally, the dot-blot assay was also validated to detect the DNA from other wheat relative species such as $H$. vulgare, A. cristatum and $S$. cereale. Thus, dot-blot hybridisation experiments were developed similarly to the ones described here for the detection of $H$. chilense genetic introgressions in the wheat background. The total $H$. vulgare genomic DNA was loaded in a membrane and detected in a dot-blot hybridisation assay using the total $H$. vulgare genomic DNA as a probe (Fig. 6a). The wheat genomic DNA was also loaded to be used as a negative control of the dot-blot in situ hybridisation. Similarly, this approach allowed the detection of A. cristatum and $S$. cereale genomic DNA (Fig. 6b, c, respectively). The ratio of each $H$. vulgare, A. cristatum and $S$. cereale total genomic probes and the wheat blocking DNA for these experiments was similar (1:300) to the one used for the detection of $H$. chilense genomic introgressions. No signals were detected for the wheat-negative control in any case. These results revealed that dot-blot hybridisation could be also used to easily screen $H$. vulgare, A. cristatum and $S$. cereale genomic introgressions in the wheat background.

\section{Discussion}

Dot-blot hybridisation assay has been revealed as a userfriendly assay that can be used as a routine tool for a rapid screening of genetic introgressions from related species in a wheat population. The method is especially useful when alien genetic introgressions are random and the screening using molecular markers would be a challenge or molecular markers cannot be associated to the introgressed segment. The total genomic DNA from $H$. chilense was labelled indistinctly with biotin-11dUTP or digoxigenin-11-dUTP and used as probes for in situ hybridisation. Probes were detected with $\mathrm{Cy} 3$ or FITC, respectively. Biotin labelling was routinely used to detect lower amounts of exotic $H$. chilense DNA in the wheat background in dot-blot experiments, although digoxigenin could also be used for DNA labelling.

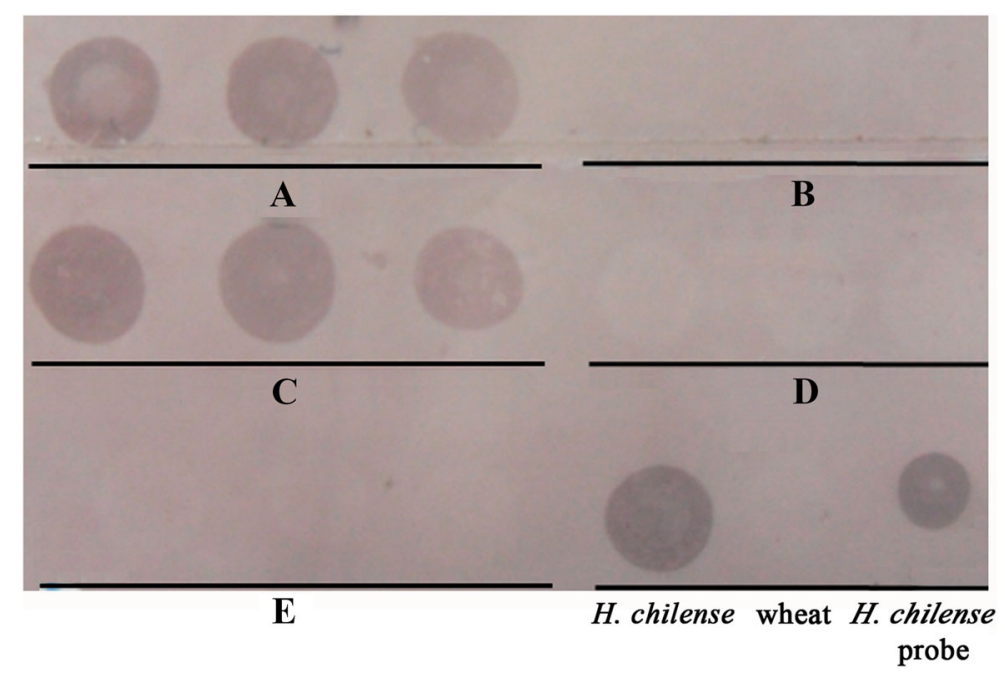

Fig. 5 Reproducibility of the dot-blot assay for the detection of H. chilense genomic introgressions in the descendants of a genetic cross between a (4B) $4 \mathbf{H}^{\text {ch }}$ monosomic substitution line and the wheat $p h l b$ mutant. Five different wheat lines were tested. Two hundreds nanograms of DNA from three equivalent $H$. chilense introgression lines (independent biological replicates) were loaded per sample. Lines $A$ and $C$ corresponded to two wheat plants carrying $H$. chilense genetic introgressions; $B, D$ and $E$ corresponded to wheat lines with no $H$. chilense chromosome introgressions. The results from the three replicates from each wheat line were consistent and the three of them were either positive or negative depending on the presence or absence of $H$. chilense introgressions in wheat. Total $H$. chilense DNA was loaded as a positive control. In addition, drops of biotin-labelled H. chilense DNA and total wheat genomic DNA were also used as positive and negative controls, respectively 


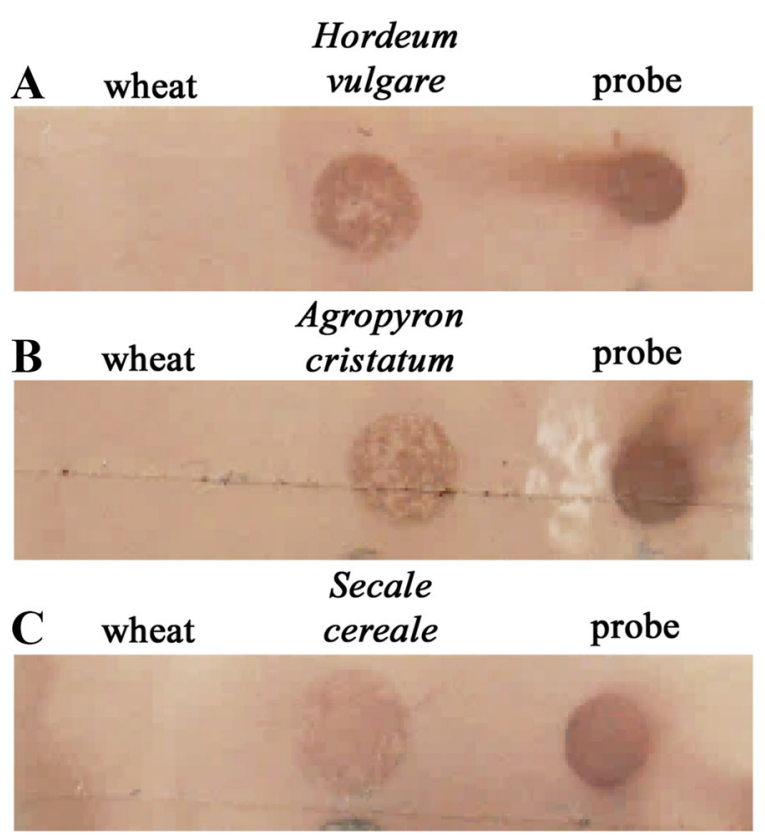

Fig. 6 Dot-blot hybridisation experiments in the wheat relatives Hordeum vulgare (a), Agropyron cristatum (b) and Secale cereale (c). Two hundred nanogrammes of total genomic DNA from each species were loaded on each membrane. Drops of biotin-labelled $H$. vulgare, A. cristatum and S. cereale DNA were used as positive controls in each experiment. Total wheat genomic DNA was always used as a negative control. $H$. vulgare, A. cristatum and $S$. cereale were successfully detected by dot-blot hybridisation, and no signals were detected for the wheat DNA samples

Nowadays, there are several techniques available for labelling and detecting alien introgression in the wheat background, including C-banding, molecular markers or in situ hybridisation. Although molecular markers and in situ hybridisation are useful tools to select the desirable plant material carrying genomic introgressions (Forster et al. 2000; Prieto et al. 2001), both techniques are high cost and time consuming. It has been estimated the high cost of labour, reagents, antibodies and fluorochromes for manual in situ hybridisation and their increment with the number of samples, due to the time required for sample manipulation and the increment of reagents to perform the protocol of a high number of samples even when some steps could be automated (Zanatta et al. 2015). It is worthy to take into account that the longest and consequently, the most expensive step during the in situ hybridisation methodology is the preparation of chromosome spreads, particularly when plants are the targets, which is not even included in estimation costs studies, due to the difficulty and variability in time of obtaining good chromosome spreads suitable for in situ hybridisation experiments. Thus, the methodology described here can reduce considerably the cost of the screening of chromosome introgressions not only because of the lower cost of the protocol itself (less reagents and no fluorochromes are needed) but also for the lower number of plants required for analysis by in situ hybridisation. On the other hand, several DNA extraction methods have been optimised for molecular marker analysis, which can also be cheaper than in situ hybridisation (Xin and Chen 2012; He et al. 2014). However, the use of molecular markers can be limited when small fragments of related species are achieved in a crop such as bread wheat, mainly because genetic maps of related species such as $H$. chilense are not saturated (Hernández et al. 2001). In addition, the use of molecular markers is based on a previous knowledge of the exact chromosome introgression to choose the most suitable markers, but can be useless when the chromosome or chromosome segment from the related species involved in recombination with the wheat chromosomes are unknown, resulting in random chromosome introgressions from the related species in the wheat background. The detection of genomic introgressions using molecular markers can also be limited by the high level of synteny among wheat and related species (Moore et al. 1995; Salse and Feuillet 2007), making it difficult to find specific markers for the introgressed chromosome fragment in the wheat background. For example, the difficulty to detect alien genomic DNA in the wheat background was already reported in Thinopyrum intermedium-wheat recombinants since there were not enough molecular markers to determine the presence of T. intermedium in wheat (Qi et al. 2007). In fact, only 9 out of 16,000 EST markers were polymorphic to define the $T$. intermedium introgression regions in the wheat background (Qi et al. 2007). In contrast, in the dot-blot experiments reported here, it was possible to unequivocally distinguish $H$. chilense genetic introgressions in the wheat background due to the optimisation of the blocking DNA concentration, which was a key step caused by the high presence of common repeat DNA sequences $(>75 \%)$ in cereals (Flavell and Smith 1976; Flavell et al. 1977; Bedbrook et al. 1980; Choulet et al. 2010; Brenchley et al. 2012). Several concentrations of wheat blocking DNA were evaluated in an attempt to enhance the sensitivity required in the dot-blot hybridisation to clearly detect $H$. chilense genetic introgressions in the wheat background. The optimal probe/blocking DNA ratio in the 
hybridisation mixture to avoid false positives (1:300) was similar to the one described by Sanchez-Moran et al. (2001), where a rate of 1:2:300 was used for A genome probe/D genome probe/B genome as blocking DNA, respectively, in the hybridisation mixture to successfully discriminate the $\mathrm{A}, \mathrm{B}$ and $\mathrm{D}$ wheat genomes in cytogenetic experiments. In addition, some other probe/ blocking DNA ratios (1:100 and 1:200) were tested in the hybridisation mixture, but in both cases, results were not convincing and false positives were detected.

On the other hand, in situ hybridisation is the most efficient and most accurate technique to estimate the genetic composition in plants or identify and characterise chromosome translocations in plants (Le et al. 1989; Schwarzacher et al. 1989; Jiang and Gill 1994) but the cost of in situ hybridisation experiments is high and requires more time and higher expertise to prepare and process the samples as it is a technically more complicated methodology. Thus, in situ hybridisation is not the most appropriate tool for screening a high number of plants from a segregating population. Therefore, in this work, we describe a more convenient and efficient method which has been extensively used for years in other plant applications (Owens and Diener 1981; Besse et al. 1997; Liu et al. 2007; Tonosaki and Nishio 2010; Vassilakos et al. 2012; Azza and Eman 2016) and does not require high qualification to prepare the samples and perform the experiments in order to identify, for example, those plants carrying exotic chromosome introgressions in a segregation population.

In fact, dot-blot hybridisation can be very useful in wheat breeding programmes when the manipulation of chromosome associations between wheat chromosomes and those from related wheat species used as genetic donors is carried out in the absence of the Phl locus (Sears 1977), which has been widely used to transfer useful genes from wild relatives into wheat to obtain resistance to biotic and abiotic stresses (Friebe et al. 1996; Xin et al. 2001; Mullan et al. 2009). The use of either only molecular markers or in situ hybridisation would be high cost and difficult in this context to locate small alien genetic introgressions, whereas dot-blot hybridisation would facilitate the screening of those chromosome introgressions, being faster, cheaper and more reliable.

Although there are a high proportion of repeated sequences in cereals, the sensitivity and reliability of the molecular hybridisation assay described here introduce a basic and simple method to detect the presence of chromosome introgressions from relative species in the wheat background. Moreover, the detection of other wheat relative species such as $H$. vulgare, $S$. cereale and $A$. cristatum in the wheat background was also possible using the dot-blot hybridisation assay. As a result, dot-blot hybridisation has been revealed as an efficient and user-friendly method for the screening and selection of plants carrying small random genomic introgressions from an alien species into the wheat germplasm, to be further fully characterised by the use of other approaches such as molecular markers or in situ hybridisation.

Acknowledgements This research was supported by grants AGL2015-64833R from the Spanish Ministerio de Economía y Competitividad (MINECO) and ERC-StG-243118 from the FP7 and The European Regional Development Fund (FEDER) from the European Union. The authors would like to thank Carmen Calderón for her technical support.

Author contribution statements MDR and PP carried out the experiments and analysed the data. MDR and PP planned the study and wrote the manuscript. Both authors read and approved the final manuscript.

Compliance with ethical standards This research does not involve human participants or animals.

Conflict of interests The authors declare that they have no competing interests.

Open Access This article is distributed under the terms of the Creative Commons Attribution 4.0 International License (http:// creativecommons.org/licenses/by/4.0/), which permits unrestricted use, distribution, and reproduction in any medium, provided you give appropriate credit to the original author(s) and the source, provide a link to the Creative Commons license, and indicate if changes were made.

\section{References}

Achim R, Anton G, Stoian M, Repanovici B (1994) Nucleic acid dot blot hybridization with fragmented digoxigenin labelled probes in human papillomavirus DNA screening. Revue Romaine de Virologie 45:109-113

Azza GF, Eman AHM (2016) Detection of stolbur phytoplasma in tomato by a specific DNA hybridization. Res J Biotechnol 11(6):30-34

Bedbrook JR, Jones J, O’Dell M, Thompson RD, Flavekk RB (1980) A molecular description of telomeric heterochromatin in Secale species. Cell 19:545-560

Besse P, McIntyre CL, Burner DM, Almeida CG (1997) Using genomic slot dot hybridization to assess intergeneric Saccharum $\times$ Erianthus hybrids (AndropogoneaeSaccharinae). Genome 40:428-432 
Borovkova IG, Steffenson BJ, Jin Y et al (1995) Identification of molecular markers linked to the stem rust resistance gene rpg4 in barley. Phytopathology 85:181-185

Brenchley R, Spannagl M, Pfeifer M et al (2012) Analysis of the bread wheat genome using whole-genome shotgun sequencing. Nature 491:705-710

Calderón MC, Ramírez MC, Martín A, Prieto P (2012) Development of Hordeum chilense $4 \mathrm{H}^{\text {ch }}$ introgression lines in durum wheat: a tool for breeders and complex trait analysis. Plant Breed 131:733-738

Castro AM, Ramos S, Vasicek A, Worland A, Giménez D, Clúa AA, Suárez E (2011) Identification of wheat chromosomes involved with different types of resistance against greenbug (Schizaphis graminum, Rond.) and the Russian wheat aphid (Diuraphis noxia, Mordvilko). Euphytica 118:321-330

Chapman V, Riley R (1955) The disomic addition of rye chromosome II to wheat. Nature 175:1091-1092

Cheley S, Anderson R (1984) A reproducible microanalytical method for the detection of specific RNA sequences by dotblot hybridization. Anal Biochem 137:15-19

Choulet F, Wickerb T, Rustenholza C et al (2010) Megabase level sequencing reveals contrasted organization and evolution patterns of the wheat gene and transposable element spaces. Plant Cell 22:1686-1701

Duveiller E, Singh RP, Nicol JM (2007) The challenges of maintaining wheat productivity: pests, diseases, and potential epidemics. Euphytica 157:417-430

Endo TR, Shi F, Tsvetkov KS (1998) Genetic induction of chromosomal structural changes of alien chromosomes in common wheat. In: A.E. Slinkard (ed.), Proc 9th Int Wheat Genet Symp, Saskatoon, Canada 2:40-43

Flavell RB, Smith DB (1976) Nucleotide sequence organization in the wheat genome. Heredity 37:231-252

Flavell RB, Rimpau J, Smith DB (1977) Repeated sequence DNA relationships in four cereal genomes. Chromosoma 63:205-222

Forster BP, Ellis RP, Thomas WTB et al (2000) The development and application of molecular markers for abiotic stress tolerance in barley. J Exp Bot 51:19-27

Friebe B, Jiang J, Gill BS, Dyck PL (1993) Radiation-induced nonhomologous wheat Agropyron intermedium chromosomal translocations conferring resistance to leaf rust. Theor Appl Genet 86:141-149

Friebe B, Zhang W, Raupp JW, Gill BS, Porter DR (1995) Nonhomoelogous wheat-rye chromosomal translocations conferring resistance to greenbug. Euphytica 84:121-125

Friebe B, Jiang J, Raupp WJ, McIntosh RA, Gill BS (1996) Characterization of wheat-alien translocations conferring resistance to diseases and pests: current status. Euphytica 91: 59-87

Graner A, Jahoor A, Schondelmaier J et al (1991) Construction of an RFLP map of barley. Theor Appl Genet 83:250-256

He J, Zhao X, Laroche A, Lu Z-X, Liu H, Li Z (2014) Genotypingby-sequencing (GBS), an ultimate marker-assisted selection (MAS) tool to accelerate plant breeding. Front Plant Sci 5:484

Hernández P, Dorado G, Prieto P et al (2001) A core genetic map of Hordeum chilense and comparisons with maps of barley (Hordeum vulgare) and wheat (Triticum aestivum). Theor Appl Genet 102:1259-1264

Islam AKMR, Shepherd KW, Sparrow DHB (1978) Production and characterization of wheat-barley addition lines. In:
Proceedings of the 5th International Wheat Genetics Symposium. Science Publishers Inc, India, pp 356-371

Islam AKMR, Shepherd KW, Sparrow DHB (1981) Isolation and characterization of euplasmic wheat-barley chromosome addition lines. Heredity 46:161-174

Jiang J, Gill BS (1994) Nonisotopic in situ hybridization and plant genome mapping: the first 10 years. Genome 37:717-725

Kimura M, Aviv A (2011) Measurement of telomere DNA content by dot blot analysis. Nucleic Acid Res 39(12):e84

Kleinhofs A, Kilian A, Maroof MAS et al (1993) A molecular, isozyme and morphological map of the barley (Hordeum vulgare) genome. Theor Appl Genet 86:705-712

Le HT, Armstrong KC, Miki B (1989) Detection of rye DNA in wheat-rye hybrids and wheat translocation stocks using total genomic DNA as a probe. Plant Mol Biol Rep 7:150-158

Liu Y, Sun B, Wang X, Zheng C, Zhou G (2007) Three digoxigenin-labelled cDNA probes for specific detection of the natural population of barley yellow dwarf viruses in China by dot blot hybridization. J Virol Methods 145:22-29

Liu W, Jin Ym Rouse M, Friebe B, Gill B, Pumphrey MO (2011) Development and characterization of wheat-Ae. searsii robertsonian translocations and a recombinant chromosome conferring resistance to stem rust. Theor Appl Genet 122: $1537-1545$

Lukaszewki AJ (2000) Manipulation of the 1RS.1BL translocation in wheat by induced homoeologous recombination. Crop Sci 40:216-225

Miller TE (1984) The homoeologous relationship between the chromosomes of rye and wheat. Current status. Can J Genet Cytol 26:579-589

Miller TE, Reader SM, Chapman (1982) The addition of Hordeum chilense chromosomes to wheat. In: C Broertjes (ed.) Proc. Int. Symp. Eucarpia on Induced Variability in Plant Breeding. Pudoc, Wageningen, pp 79-81

Molnár-Láng M, Linc G, Friebe BR, Sutka J (2000) Detection of wheat-barley translocations by genomic in situ hybridization in derivatives of hybrids multiplied in vitro. Euphytica 112: $117-123$

Molnár-Láng M, Kruppa K, Cseh A, Bucsi J, Linc G (2012) Identification and phenotypic description of new wheat-sixrowed winter barley disomic additions. Genome 55:302-311

Moore G, Devos KM, Wang Z, Gale MD (1995) Grasses, line up and form a circle. Curr Biol 5(7):737-739

Mullan DJ, Mirzaghaderi G, Walker E, Colmer TD, Francki MG (2009) Development of wheat-Lophopyrum elongatum recombinant lines for enhanced sodium 'exclusion'during salinity stress. Theor Appl Genet 119:1313-1323

Murray YHG, Thompson WF (1980) Rapid isolation of high molecular weight plant DNA. Nucleic Acids Res 8:43214326

Okamoto M (1957) A synaptic effect of chromosome V. Wheat Information Service 5:6

Owens RB, Diener TO (1981) Sensitive and rapid diagnosis of potato spindle tuber viroid disease by nucleic acid hybridization. Science 213:670-672

Prieto P, Ramírez MC, Ballesteros J, Cabrera A (2001) Identification of intergenomic translocations involving wheat, Hordeum vulgare and Hordeum chilense chromosomes by FISH. Hereditas 135:171-174 
Prieto P, Shaw P, Moore G (2004a) Homologue recognition during meiosis is associated with a change in chromatin conformation. Nat Cell Biol 6:906-908

Prieto P, Martin A, Cabrera A (2004b) Chromosomal distribution of telomeric and telomeric-associated sequences in Hordeum chilense by in situ hybridization. Hereditas 141:122-127

Qi LL, Friebe B, Zhang P, Gill BS (2007) Homoeologous recombination, chromosome engineering and crop improvement. Chromosom Res 15:3-19

Qi LL, Pumphrey MO, Friebe B, Chen PD, Gill BS (2008) Molecular cytogenetic characterization of alien introgressions with gene Fhb3 for resistance to Fusarium head blight disease of wheat. Theor Appl Genet 117:1155-1166

Rey MD, Calderon MC, Prieto P (2015) The use of the phlb mutant to induce recombination between the chromosomes of wheat and barley. Front Plant Sci 6:160

Riley R, Chapman V (1958a) The production and phenotypes of wheat-rye chromosome addition lines. Heredity 12:301-315

Riley R, Chapman V (1958b) Genetic control of the cytologically diploid behaviour of hexaploid wheat. Nature 182:713-715

Riley R, Chapman V, Johnson R (1968) Introduction of yellow rust resistance of Aegilops comosa into wheat by genetically induced homoeologous recombination. Nature 217:383-384

Rubiales D, Reader SM, Martín A (2000) Chromosomal location of resistance to Septoria tritici in Hordeum chilense determined by the study of chromosomal addition and substitution lines in 'Chinese Spring' wheat. Euphytica 115:221-224

Salse J, Feuillet C (2007) Comparative genomics of cereals. In: Varshney, RK and Tuberosa, R (eds) Genomics-assisted crop improvement: volume 1: genomics approaches and platforms, pp. 177-205, Springer Verlag

Sanchez-Moran E, Benavente E, Orellana J (2001) Analysis of karyotypic stability of homoeologous-pairing $(p h)$ mutants in allopolyploid wheats. Chromosoma 110(5):371-377

Schwarzacher T, Leitch AR, Bennett MD, Heslop-Harrison JS (1989) In situ localization of parental genomes in a wild hybrid. Ann Bot 64:315-324

Sears ER (1956) The transfer of leaf rust resistance from Aegilops umbellulata to wheat. Brookhaven Symp Biol 9:1-22
Sears ER (1977) Induced mutant with homoeologous pairing in common wheat. Can J Genet Cytol 19:585-593

Sears ER (1981) Transfer of alien genetic material to wheat in the wheat science - today and tomorrow. D. Evans, Peacock WI (eds.) Cambridge University Press, UK, pp 75-89

Sears ER (1982) A wheat mutation conditioning an intermediate level of homoeologous chromosome pairing. Can J Genet Cytol 24:715-719

Sears ER, Okamoto M (1958) Intergenomic chromosome relationship in hexaploid wheat. Proc. 10th Int. Cong. Genet., Montreal, Canada. 258-259

Szakács É, Molnár-Láng M (2006) Development and molecular cytogenetic identification of new winter wheat-winter barley ('Martonvásári 9 krl'-'Igri') disomic addition lines. Genome 50:43-50

Tonosaki K, Nishio T (2010) Identification of species in tribe Brassiceae by dot-blot hybridization using species-specific ITS1 probes. Plant Cell Rep 29:1179-1186

Vassilakos N, Kektsidou OI, Papaeythimiou M, Vervari C (2012) Comparison of direct-RT-PCR and dot-blot hybridization for the detection of potato spindle tuber viroid in natural host plant species. Eur J Plant Pathol 134:85-864

Xin Z, Chen J (2012) A high throughput DNA extraction method with high yield and quality. Plant Methods 8:26

Xin ZY, Zhang ZY, Chen X et al (2001) Development and characterization of common wheat-Thinopyrum intermedium translocation lines with resistance to barley yellow dwarf virus. Euphytica 119:161-165

Zanatta L, Valori L, Cappelletto E, Pozzebon ME, Pavan E, Dei Tos AP, Merkle D (2015) Reagent and labor cost optimization through automation of fluorescence in situ hybridisation (FISH) with the VP 2000: an Italian case of study. J Lab Autom 20:25-31

Zhao R, Wang H, Xiao J, Bie T et al (2013) Induction of 4VS chromosome recombinants using the CS phlb mutant and mapping of the wheat yellow mosaic virus resistance gene from Haynaldia villosa. Theor Appl Genet 126: 2921-2930 